\title{
Articles
}

\section{Currency Manipulation and WTO Laws: Should the Anti-Dumping Mechanism Be Entirely Dumped?}

\author{
Chen $\mathrm{Yu}$ \\ McGill University, Montreal, Canada \\ chen.yu@mail.mcgill.ca
}

\begin{abstract}
Currency devaluation resembles subsidy and dumping in terms of its impact on global trade - it grants price advantages to exporting companies. Unlike subsidy and dumping, however, multilateral regulation of currency manipulation is far from sufficient. The World Trade Organization (WTO), whose core principles are undermined by currency manipulation, plays no role in the regulatory framework. This article discusses possible avenues for the WTO to combat currency manipulation in future negotiations. Particularly, it proposes a new approach, which is to allow the application of the surrogate price method in anti-dumping investigations against currency manipulators. The anti-dumping mechanism has long been overlooked in the relevant literature as it is believed to combat company-level activities rather than State-level activities. This new approach proposes to treat fundamental exchange rate misalignment as a special market condition which allows anti-dumping investigation authorities to use the surrogate price method to eliminate the trade distortion caused by it.
\end{abstract}

* Chen $\mathrm{Yu}$ is a PhD candidate at McGill University (Room 6o2, New Chancellor Day Hall, 3644 Peel St, Montreal, QC H3A 1W9). The author would like to thank her PhD supervisor, Professor Fabien Gélinas, for sharing his insights with regards to this article, and her master's supervisor, Professor Frédéric Bachand (as he then was, the now Justice Bachand), for his guidance on the master's thesis. She would also like to thank Lucas Clover Alcolea, Jewelz Jules and Ynes Julie Ada for their comments and suggestions. 


\section{Keywords}

anti-dumping - currency manipulation - WTO laws

\section{Background: The Problem of Currency Manipulation}

Recently, the conclusion of the United States-Mexico-Canada Agreement (USMCA), which is formerly known as the North American Free Trade Agreement (NAFTA), brings the issue of currency manipulation back to public attention as it includes a chapter deterring the parties from intervening in the foreign exchange market. ${ }^{1}$ Although the obligation is principally hortatory, ${ }^{2}$ it marks a new step of international regulation of currency manipulation as it explicitly addresses the issue in free trade agreements (FTA). ${ }^{3}$ Currency manipulation has long been criticized for distorting international trade. The devaluation of a country's currency enables its exporting companies to offer lower prices in foreign currencies, which grants them an additional advantage in cross-border transactions. As a result, it impairs the export of similar products from non-manipulating countries as well as the domestic consumption in the importing countries. In other words, currency manipulation may grant unfair competitive advantages to those companies in the exporting country.

Empirical research by the United Nations Conference on Trade and Development (UNCTAD) finds that exchange rate misalignment has a substantial influence on international trade and causes trade diversion quantifiable in about one percent of world trade. ${ }^{4}$ It is blamed for having caused the United States' huge trade deficit and is described to be 'the world's most

1 United States-Mexico-Canada Agreement (signed 30 November 2018) (USMCA) ch 33.

2 According to art 33.6-33.8 of the USMCA, the substantive obligation of avoiding currency manipulation is enforced via the surveillance of the Macroeconomic Committee as well as the consultations between the parties, while the dispute settlement mechanism only applies to violation of obligations relating to transparency and reporting.

3 See C Fred Bergsten, 'A Positive Step in the USMCA: Countering Currency Manipulation' (2018) Peterson Institute for International Economics <www.piie.com/blogs/trade-investment-policy-watch/positive-step-usmca-countering-currency-manipulation> accessed 4 April 2019 (" $\mathrm{i}] \mathrm{t}$ is the first trade agreement in history to directly address an issue that has aroused opposition to such agreements in the past - currency manipulation by trading partners').

4 Alessandro Nicita, 'Exchange Rates, International Trade and Trade Policies' (2013) 56 UNCTAD Study Series $2<$ http://linkinghub.elsevier.com/retrieve/pii/S2110701713000371> accessed 12 April 2019. 
protectionist international economic policy in the 21st century. ${ }^{5}$ On the other hand, expansionary monetary policies such as quantitative easing $(\mathrm{QE})$ adopted by the United States can also cause currency devaluation and impact other economies. ${ }^{6}$ This creates a situation similar to 'currency wars' and thus significantly impairs the international monetary order. The existence of global supply chains in international trade may contribute to mitigating trade distortions caused by exchange rate misalignment, ${ }^{7}$ while the degree of such an effect is quite uncertain. It can be affected by several elements, for example, the level of the export products in the supply chain (raw materials versus intermediate products) and for intermediate products, the supply of local products versus imports in the raw materials market.

Apart from economic impacts, currency manipulation is also criticized for undermining fundamental international principles such as the most favored nation (MFN) principle, the national treatment principle and tariff bindings in World Trade Organization (WTO) laws. ${ }^{8}$ Thus, it is not surprising that international organizations and governments attach great importance to the issue. The International Monetary Fund (IMF) makes assessments on its members' currency policies periodically to examine whether they are consistent with Article IV of the IMF Articles of Agreement which includes a provision prohibiting the members from manipulating currency. ${ }^{9}$ For example, in 2014, it found South Korea's currency won being 'moderately undervalued in real effective

5 C Fred Bergsten, 'Currency Manipulation: Why Something Must Be Done' (Forbes 2015) $<$ www.forbes.com/sites/realspin/2015/02/25/currency-manipulation-why-something-must -be-done/\#6d3ciff331c8> accessed 28 April 2019.

6 Emilios Avgouleas, 'The Incomplete Global Financial Order and Spillovers from Instability in Trade and Currency Market Regimes' in Emilios Avgouleas and David C Donald (eds), The Political Economy of Financial Regulation (CUP 2019) 289.

7 Gary W Williams and Ji Luo, 'Exchange Rate Policy and Global Supply Chains: The Case of the Chinese Renminbi and Global Soybean and Soybean Product Markets' (2017) 39 Applied Economic Perspectives and Policy 177, 194 ('[b]ecause exchange rate adjustments impact all market segments along a supply chain simultaneously, however, the effects on any one segment can be confounded by the transmission of the effects on other segments up and down the supply chain'). For example, if a Chinese producer relies greatly on a raw material that is imported rather than domestically produced, after devaluation of the Chinese yuan, the import prices of the material increases, consequently, the producer's cost of production increases. As a result, he may quote a higher export price, which can to some extent offset the price advantages granted by currency devaluation in the export market.

8 Jeffrey S Beckington and Matthew R Amon, 'Competitive Currency Depreciation: The Need for a More Effective International Legal Regime' (2011) 10 Journal of International Business and Law 209, 222-35.

9 Articles of Agreement of the International Monetary Fund (adopted 22 July 1944, entered into force 27 December 1945) 2 UNTS 39 (IMF Articles of Agreement) art IV1(iii). 
terms.10 The United States Department of the Treasury also publishes semiannual reports on the foreign exchange rate policies of its major trade partners. ${ }^{11}$ However, despite all these measures, as will be explained in the section below, international laws have played a modest role in combating currency manipulation: the IMF Articles of Agreement prohibits currency manipulation for the purpose of gaining unfair competitive advantages while it lacks strong enforcement mechanisms to implement the obligation; with respect to the WTO, the issue is generally considered to not fall into the organization's jurisdiction.

Against this background, this article moves on to discuss the possible avenues for the WTO to regulate currency manipulation in future treaty negotiations. The first one, as has been discussed by a few scholars and will be analyzed in section 3 below, is to conclude a cooperation agreement with the IMF so that currency manipulation provisions can be adopted or enforced by the WTO. However, this article finds that this development has legal basis but lacks feasibility. In turn, it highlights an indirect avenue for the WTO to regulate currency manipulation that has been overlooked in previous discussions - the anti-dumping mechanism. As will be presented in section 4 and 5 , the surrogate price method in the anti-dumping mechanism contributes to eliminating the price advantage granted by currency devaluation. Thus, this article proposes to treat currency manipulation as a special market condition like that of the 'non-market economy' (NME) in the anti-dumping rules so that an investigation authority is allowed to use a third-country price as the normal value to determine the dumping margin. This still requires the WTO members to amend the current agreements, but it avoids unreasonably enlarging the regulatory scope of the WTO and is both legally and technically more feasible than previous proposals. It is important to note that this article does not attempt to provide or design a perfect solution to the problem but simply to point out a relatively feasible and balanced avenue towards future regulation.

10 IMF, 'Press Release No. 14/20 IMF Executive Board Concludes 2013 Article IV Consultation with the Republic of Korea' (22 January 2014) <www.imf.org/external/np/sec/pr/2014/ pri420.htm> accessed 28 April 2019.

11 See US Department of the Treasury, 'Macroeconomic and Foreign Exchange Policies of Major Trading Partners of the United States' <http://home.treasury.gov/system/ files/206/2018-10-17-\%28Fall-2018-FX\%2oReport\%29.pdf> accessed 23 April 2019. 
Currently, currency manipulation is mainly regulated by Article IV1(iii) of the IMF Articles of Agreement which requires that a Member State shall 'avoid manipulating exchange rates or the international monetary system in order to prevent effective balance of payments adjustment or to gain an unfair competitive advantage over other members'.12 The 2007 Decision on Bilateral Surveillance over Members' Policies (the 2007 Surveillance Decision) further specifies that the purpose of gaining 'unfair competitive advantage' is to 'increase net exports.' ${ }^{13}$ However, the bindingness of the IMF's regulation is greatly diminished due to the lack of effective dispute settlement and enforcement mechanisms. ${ }^{14}$ According to the IMF Articles of Agreement, Article IV1(iii) is implemented via the IMF's surveillance over its members' exchange arrangements, during which process they are obliged to provide the necessary information and consult with the IMF when requested. ${ }^{15}$ Unlike other multilateral mechanisms (e.g. the WTO), the IMF Articles of Agreement do not grant a member the opportunity to initiate a complaint against another member's violation of obligations, neither does it provide immediate sanctions for noncompliance with the IMF Executive Board's decisions. Despite the IMF's endeavor to enhance surveillance and monitoring activities in recent years, ${ }^{16}$ the role it can play in the regulation of currency issues is inherently limited, probably because it works more like a 'foreign aid agency' rather than a regulatory institution. ${ }^{17}$

At the same time, increasing attention has been paid to the WTO to regulate currency manipulation because it has an effective dispute settlement and enforcement mechanism. This consideration is not unreasonable given that the fluctuation of exchange rates has a significant influence on international trade. Moreover, as will be discussed below, the WTO has the obligation to consult the IMF with regards to exchange rate issues in its decision-making

12 IMF Articles of Agreement (n 9) art IV1(iii).

13 IMF, 'Bilateral Surveillance over Members' Policies' (adopted 15 June 2007) Executive Board Decision 13919-(07/51) (the 2007 Surveillance Decision), Annex Article IV, Section 1(iii) and Principle A, para 2(b).

14 See Laurence Howard, 'Chinese Currency Manipulation: Are There Any Solutions?' (2013) 27 Emory Intl Law Rev 1215, 1225.

15 IMF Articles of Agreement (n 9) art IV3.

16 See eg IMF, 'IMF Surveillance' < www.imf.org/en/About/Factsheets/IMF-Surveillance> accessed 9 April 2019.

17 Andreas F Lowenfeld, 'The International Monetary System: A Look Back over Seven Decades' in Thomas Cottier, John H Jackson and Rose M Lastra (eds), International Law in Financial Regulation and Monetary Affairs (OUP 2012) 52, 62. 
process, which builds the bridge for the two organizations to cooperate on the regulation of currency manipulation..$^{18}$ Efforts have been made to analyze whether the WTO agreements, especially the Agreement on Subsidies and Countervailing Measures (SCM Agreement) and the General Agreement on Tariffs and Trade (GATT) Article XV:4, apply to currency manipulation. ${ }^{19}$ The SCM Agreement is frequently discussed because the price advantage rendered by currency devaluation to a large extent resembles a subsidy. According to the SCM Agreement, a subsidy exists if there is (1) a financial contribution by a government or any public body, (2) a benefit is thereby conferred and (3) the subsidy is specific to an enterprise or industry or group of enterprises

18 See General Agreement on Tariffs and Trade 1994 (adopted 15 April 1994, entered into force 1 January 1995) 55 UNTS 194 (GATT) art XV(2) and (3).

19 See eg Benjamin Blase Caryl, 'Is China's Currency Regime a Countervailable Subsidy? A Legal Analysis Under the World Trade Organization's SCM Agreement' (2011) 45 JWT 187; Aluisio de Lima-Campos \& Juan Antonio Gaviria, 'A Case for Misaligned Currencies as Countervailable Subsidies' (2012) 46 JWT 1017; Elizabeth L Pettis, 'Is China's Manipulation of Its Currency an Actionable Violation of the IMF and/or the WTO Agreements?' (2011) 10 Journal of International Business and Law 281; Annamaria Viterbo, International Economic Law and Monetary Measures: Limitations to States' Sovereignty and Dispute Settlement (Edward Elgar 2012), 296; Catharina E Koops, 'Manipulating the WTO? The Possibilities for Challenging Undervalued Currencies Under WTO Rules' (2010) Amsterdam Center for International Law Research Papers $2010<$ http://papers. ssrn.com/sol3/papers.cfm?abstract_id=1564093> accessed 28 April 2017; Haneul Jung, 'Tackling Currency Manipulation with International Law: Why and How Currency Manipulation Should be Adjudicated?' (2012) 9 Manchester Journal of International Economic Law 184; Sohlberg Marcus, 'The China Currency Issue: Why the World Trade Organization Would Fail to Provide the United States with an Effective Remedy' (2011) Cornell Law School Inter-University Graduate Student Papers 43; Matthew R Leviton, 'Is It a Subsidy? An Evaluation of China's Currency Regime and Its Compliance with the WTO' (2005) 23 Pacific Basin Law Journal 243; Nathan Fudge, 'Walter Mitty and the Dragon: An Analysis of the Possibility for WTO or IMF Action Against China's Manipulation of the Yuan' (2011) 45 JWT 349; Bryan Mercurio \& Celine Sze Ning Leung, 'Is China a "Currency Manipulator"?: The Legitimacy of China's Exchange Regime Under the Current International Legal Framework' (2009) 43 The International Lawyer 1257; Robert W Staiger \& Alan O Sykes, “Currency Manipulation” and World Trade' (2010) 9 The World Trade Rev 583; Vera Thorstensen, Carolina Muler \& Daniel Ramos, 'Exchange Rate Measures: Who Judges the Issue - IMF or WTO?' (2015) $18 \mathrm{~J}$ Intl Econ L 117; Claus D Zimmermann, 'Exchange Rate Misalignment and International Law' (2011) 105 AJIL 423; Gabrielle Z Marceau \& Jone J Maughan, 'The WTO Dispute Settlement Mechanism in Matters Involving Exchange Rate and Trade' in Thomas Cottier and others (eds), The Rule of Law in Monetary Affairs: World Trade Forum (CUP 2014) 366; Gregory Hudson, Pedro Bento de Faria and Tobias Peyerl, "The Legality of Exchange Rate Undervaluation Under WTO Law' (2011) The Graduate Institute Centre for Trade and Economic Integration Working Paper CTEI-2001-07 <http://repository.graduateinstitute.ch/record/294799> accessed 22 April 2019. 
or industries. ${ }^{20}$ Besides, if the measure is defined as a prohibited export subsidy under Article III, it is deemed to meet the specificity requirement. ${ }^{21}$ Most studies, after analyzing the text of the articles, concludes that currency manipulation fails to satisfy all the above requirements of being a subsidy. ${ }^{22}$ With regards to the GATT, Article XV:4 requires that '[c] ontracting parties shall not, by exchange action, frustrate the intent of the provisions of this Agreement, nor, by trade action, the intent of the provisions of the Articles of Agreement of the International Monetary Fund'. ${ }^{23}$ Currency manipulation can be interpreted to be an exchange action for the purpose of Article XV:4; however, there is no legal basis suggesting that it frustrates the intent of any provisions of the GATT. ${ }^{24}$ In a word, there is little chance that a claim asserting that currency manipulation violates a current WTO rule will be supported by the WTO Dispute Settlement Body (DSB).

In theory, the WTO and the IMF are designed to work cooperatively to regulate currency manipulation. GATT Article XV paragraph 1 requires that the WTO members shall cooperate with the IMF and pursue a coordinated policy on exchange issues. ${ }^{25}$ Paragraph 2 further addresses that the members shall 'consult fully with' and 'accept all findings of statistical and other facts presented by the Fund relating to foreign exchange' and accept its determination on whether an action violates the IMF Articles of Agreement. ${ }^{26}$ Besides, based on the mutual appreciation of cooperation, the two organizations reached the Agreement Between the International Monetary Fund and the World Trade Organization. Paragraph 8 of the agreement stipulates that the IMF shall inform the WTO (including the DSB) on whether the exchange actions within IMF's jurisdiction is consistent with the IMF Articles of Agreement. ${ }^{27}$ The Agreed Commentary on the article further specifies that the paragraph applies to GATT Article XV and The General Agreement on Trade in Services

20 See Agreement on Subsidies and Countervailing Measures (adopted 15 April 1994, entered into force 1 January 1995) Marrakesh Agreement Establishing the World Trade Organization, Annex 1A, 1869 UNTS 14 (SCM Agreement) arts I \& II.

21 ibid. The SCM Agreement art III states that 'subsidies contingent, in law or in fact, whether solely or as one of several other conditions, upon export performance, including those illustrated in Annex I (5)' shall be prohibited (emphases added).

22 See eg Lima-Campos and Gaviria (n 19) 1029; Fudge (n 19).

23 GATT (n 18) art XV:4 (emphasis added).

24 See Fudge (n 19), 359-61.

25 GATT (n 18) art XV para 1.

26 ibid art XV para 2.

27 Agreement Between the International Monetary Fund and the World Trade Organization (adopted 18 November 1996) Decision No. 11381-(96/105) in WTO Agreements with the Fund and the Bank WT/L/195, para 8. 
(GATS) Article XI, both of which include provisions relating to the WTO-IMF cooperation. ${ }^{28}$

Although the Agreement Between the IMF and the WTO has connected the IMF Articles of Agreement and the WTO dispute settlement mechanism, it leaves a gap with regards to the regulation of currency manipulation. It can be concluded from a holistic review of all the above-mentioned provisions that, the premise to enforce the IMF's findings regarding currency manipulation through the WTO dispute settlement mechanism is that the measure at issue (1) is complained to the WTO and (2) is found by the panel or the appellate body $(\mathrm{AB})$ to violate the second half of GATT Article XV:4 ('Contracting parties shall not ... by trade action, [frustrate] the intent of the provisions of the Articles of Agreement of the International Monetary Fund' [emphasis added]). However, since currency manipulation is in nature an exchange action rather than a trade action, it is not likely that the DSB will support a complaint arising out of it. ${ }^{29}$ Consequently, the IMF's decisions have no chance to be enforced through the WTO dispute settlement mechanism.

To conclude, this section discussed two possible avenues to regulate currency manipulation via the current WTO framework: (1) to directly claim that currency manipulation violates an existing WTO obligation or (2) to enforce IMF's finding that a measure violates Article IV1(iii) of the IMF Articles of Agreement through GATT Article XV:4 and the Agreement Between the IMF and the WTO. It concludes that both avenues are unlikely to succeed. Thus, as will be discussed in section 3, it is not surprising that there are suggestions to modify the current agreements or to conclude new agreements to address the issue.

\section{3}

\section{Directly Regulating Currency Manipulation Lacks Feasibility}

Suggestions regarding IMF and WTO's future reforms to combat currency manipulation are either to incorporate Article IV1(iii) of the IMF Articles of Agreement into the substantive WTO obligations or to make Article IV1(iii)

\footnotetext{
28 ibid annex III para 8.

29 See Mercurio and Leung (n 19) 1286. In addition, as the Special Sub-Group set up in 1954 during the Review Session noted, the division between trade action and exchange action was in practice 'based on the technical nature of government measures rather than on the effect of these measures on international trade and finance'. WTO, 'Analytical Index of the GATT Article XV' 435 <www.wto.org/english/res_e/publications_e/ai17_e/gatt1994_ art15_gatt47.pdf $>$ accessed 22 April 2019.
} 
litigable to the WTO DSB. ${ }^{30}$ For example, it is argued that, in order to achieve effective cooperation between the two organizations, a new framework prohibiting currency regulation must be established. ${ }^{31}$ The basic idea is that one WTO member challenges the other for violating the obligation of avoiding currency manipulation in the WTO; then a panel constituted by IMF experts is established to review the currency policy in dispute; after that, the findings shall be implemented via the WTO enforcement mechanism. ${ }^{32}$ Although there might be different viewpoints regarding the bindingness of the IMF's decisions on WTO panels, the proposed frameworks are similar: the IMF deals with the technical analysis of the member's currency policy because it has more expertise in currency issues and its findings are enforced through the WTO dispute settlement mechanism.

This is a straightforward solution to the currency manipulation problem. However, it is unlikely to be politically feasible. Supposing that some countries, which are both WTO and IMF members, plan to initiate the negotiation of the new cooperation agreement to regulate currency manipulation, they will have to (1) get the consensus of the WTO members to add 'avoiding to manipulation currency' to the WTO legal system as a new obligation, ${ }^{33}$ or (2) get no less than 'three-fifths of the members, having eighty-five percent of the total voting power' to agree to subject IMF Articles of Agreement Article IV1(iii) to the jurisdiction of the WTO dispute settlement mechanism. ${ }^{34}$ In practice, it is

30 There is also a proposal to establish a WTO-style dispute settlement mechanism under the IMF to enforce the 2007 Surveillance Decision. Paul Blustein, 'A Flop and a Debacle: Inside the IMF's Global Rebalancing Acts' (2012) CIGI Papers No 4, 32-33 $<$ www.cigionline.org/publications/flop-and-debacle-inside-imfs-global-rebalancing -acts $>$ accessed 27 April 2019.

31 Gary Clyde Hufbauer and Jeffrey J Schott, 'Will the World Trade Organization Enjoy a Bright Future?' (2012) Peterson Institute for International Economics Working Paper No PB 12-11, 12 <http://piie.com/publications/policy-briefs/will-world-trade-organizationenjoy-bright-future $>$ accessed 9 November 2017.

32 ibid. See also Aaditya Mattoo \& Arvind Subramanian, 'Currency Undervaluation and Sovereign Wealth Funds: A New Role for the World Trade Organization' (2008) Peterson Institute for International Economics Working Paper No WP 08-2 <http://piie.com/ publications/working-papers/currency-undervaluation-and-sovereign-wealth-funds -new-role-world-trade> accessed 28 April 2019. Unlike Hufbauer and Schott, the authors propose to amend the current WTO agreements to establish new rules regulating currency manipulation.

33 See Marrakesh Agreement Establishing the World Trade Organization (adopted 15 April 1994, entered into force 1 January 1995) 1867 UNTS 154, 33 ILM 1144, annex 1A art IX. The article stipulates that ' $[\mathrm{t}] \mathrm{he}$ WTO shall continue the practice of decision-making by consensus followed under GATT 1947'.

34 IMF Articles of Agreement (n 9) arts X and XXVIII. Article X stipulates that "[a]ny arrangements for such cooperation which would involve a modification of any provision of 
questionable whether there will be adequate support to pass the proposal. It is obvious that countries who have been criticized for manipulating their currencies are not likely to vote for the new agreement. ${ }^{35}$ Moreover, members who claim to be victims of currency manipulation can also be reluctant to subject the issue to the joint regulation of the IMF and the WTO. For them, an important concern is that the IMF would be vested with too much regulatory power governing the members' currency arrangements, as a result of which their sovereignty would be hindered. ${ }^{36}$ The measure the United States took against China's peg-to-dollar currency policy is evidence of this argument. Despite domestic petitions to impose trade sanctions on products from China, the United States government insisted on imposing political pressure on Beijing. ${ }^{37}$ The foreign exchange policy report published by the United States treasury office also indicates its careful attitude towards currency policies: the criteria relating to exchange rate policies set forth in the report are technically rather strict. For example, it only takes account of exchange rate interventions that are conducted repeatedly, as a result of which most countries are excluded from the scope of currency manipulators. ${ }^{38}$

Besides, the recent trend of regional trade agreements can also shed light on the future of the new agreement regulating currency manipulation. Compared with multilateral agreements, regional agreements can be expected to be more advanced in terms of facilitating fair trade and easier to reach consensus among the parties because they are concluded by a smaller number of states

this Agreement may be effected only after amendment to this Agreement under Article XXVIII'. Article XXVIII stipulates that '[w] hen three-fifths of the members, having eighty-five percent of the total voting power, have accepted the proposed amendment, the Fund shall certify the fact by a formal communication addressed to all members'.

For example, the United States put China, Japan, Korea, Germany, Italy, Ireland, Singapore, Malaysia, and Vietnam on the 'Monitoring List' in its congress report 'Macroeconomic and Foreign Exchange Policies of Major Trading Partners of the United States' because their economy condition satisfies one or two of the following criteria: (1) a significant bilateral trade surplus with the United States, (2) a material current account surplus, and (3) engaged in persistent one-sided intervention in the foreign exchange market.

Although only Singapore is currently found to satisfy criterion (3), it is still quite likely that all countries mentioned will adopt a precautionary attitude against the new regulatory framework.

US Department of the Treasury, 'Macroeconomic and Foreign Exchange Policies of Major Trading Partners of the United States' (May 2019) (US Exchange Policy Report) <https:// home.treasury.gov/system/files/206/2019-05-28-May-2019-FX-Report.pdf> accessed 14 October 2019 .

36 Howard (n 14) 1230.

37 See HKTDC, USTR Rejects Section 301 “Currency Manipulation” Petition' (23 September 2014) <http://info.hktdc.com/alert/uso418a.htm> accessed 28 April 2019.

38 See US Exchange Policy Report (n 35) 4. 
who have closer interests. One example was the Trans-Pacific Partnership (TPP) Agreement which had higher standards on fair trade and governmental regulation coordination than previous regional agreements. ${ }^{39}$ In the United States, during the negotiation of the TPP, there were petitions from the Congress, non-governmental groups, and economists to establish 'strong and enforceable currency disciplines' in the agreement. ${ }^{40}$ However, eventually, the agreement still failed to address exchange rate issues in its formal text. Instead, the issues were stipulated in a side agreement, Joint Declaration of the Macroeconomic Policy Authorities of Trans-Pacific Partnership Countries, which reiterated the obligation to avoid currency manipulation but had no enforcement mechanism. ${ }^{41}$ This indicates that although the TPP members had concerns on exchange rate issues, they failed to reach consensus to, or were not willing to, make currency manipulation an enforceable violation of international obligation.

\section{The Anti-Dumping Mechanism and Currency Manipulation}

It has been mentioned above that currency manipulation is not likely to violate the current WTO agreements including the SCM Agreement and GATT; it is also argued that the attempt to escalate the avoidance of exchange rate manipulation into an enforceable international obligation lacks feasibility. In other words, this article disagrees with most previous proposals on regulating currency manipulation through the WTO mechanism. However, to the extent that currency manipulation does distort international trade, the WTO should play a role in minimizing the adverse effects caused by currency misalignment. This section points out a workable option for reaching this end - to treat currency manipulation as a special market condition like that of the NME, which will allow anti-dumping investigating authorities to use surrogate country prices of like products to calculate the dumping margin. The following paragraphs will explain why it works.

39 The Trans-Pacific Partnership Agreement (signed 4 February 2016) <https://ustr.gov/ trade-agreements/free-trade-agreements/trans-pacific-partnership/tpp-full-text> accessed 14 October 2019.

$40 \quad$ Rep Sandy Levin, 'The Need to Address Currency Manipulation in TPP, and Why US Monetary Policy Is Not at Risk' (HUFFPOST, 6 February 2016) <www.huffingtonpost .com/rep-sander-/the-need-to-address-curre_b_6631514.html $>$ accessed 28 April 2019.

41 Joseph E Gagnon, 'More on TPP and Exchange Rates' (2015) Peterson Institute for International <www.piie.com/blogs/trade-investment-policy-watch/more-tpp-and -exchange-rates $>$ accessed 28 April 2019. 
Unlike subsidy, dumping does not resemble currency manipulation in many aspects. The most distinct difference is that dumping is usually considered to be conducted by private companies rather than governments. ${ }^{42}$ Nevertheless, dumping and currency manipulation lead to the same result: a lower exporting price which grants the exporting companies unfair advantages in international trade. Moreover, since anti-dumping investigations only focus on whether there is a lower export price rather than how the lower price is formed, it does not exclude circumstances where currency devaluation is also a cause of the lower price. That is to say, if an anti-dumping duty is imposed to offset the price advantage of the exporting company, it may at the same time offset the impact of currency devaluation. ${ }^{43}$

According to GATT Article VI:1, when 'products of one country are introduced into the commerce of another country at less than the normal value of the products', there is dumping. ${ }^{44}$ The WTO does not categorically condemn dumping activities but only those that cause or threaten 'material injury to an established industry in the territory of a contracting party or materially retards the establishment of a domestic industry'.45 Upon the determination of the existence of dumping and the causation of material injury thereby, the importing State can impose anti-dumping duties on the imports. It is also required that the punitive duty must not exceed the dumping margin, which is the difference between the normal value and the export price of the product. ${ }^{46}$ In other words, dumping margin determines whether there exists dumping as well as the maximum amount of anti-dumping duty. Therefore, to analyze the relationship between currency manipulation and the anti-dumping mechanism, the core issue is how currency devaluation influences the calculation of dumping margin in anti-dumping investigations.

GATT Article VI: has detailed instructions on how to ascertain the normal value of a product. Generally, the normal value should be the price of like products for domestic consumption in the exporting country (the 'domestic

\footnotetext{
42 See Koops (n 19) 6-8.

43 See below at $\mathrm{nn} 5^{6-58}$ and accompanying text.

44 GATT (n 18) art VI:1.

45 ibid. Article 3 of the Anti-Dumping Agreement further stipulates that a determination of injury 'shall be based on positive evidence and involve an objective examination of both (a) the volume of the dumped imports and the effect of the dumped imports on prices in the domestic market for like products, and (b) the consequent impact of these imports on domestic producers of such products'.

46 ibid para 2.
} 
price'). ${ }^{47}$ If such price is not available, the investigating authority may take the highest comparable price of like products exporting to a third country as the substitution price (the 'third-country price'), or construct the normal value on its own according to the cost of producing and selling the product plus reasonable profits (the 'constructive value'). ${ }^{48}$ All of the three methods ascertain the normal value based on the price of like products (or the inputs of the products) in the exporting country. Apart from the normal methods of calculating dumping margin, there is also a special method, namely the surrogate price method, for countries which accept to be treated as NME in their accession protocols. ${ }^{49}$ The reason to provide differential treatments to NMEs in anti-dumping investigations is that, in those economies, prices of goods are not determined by the demand and supply in the market but may be distorted by government interventions; as a result, domestic prices fail to reflect the real value of products. This concern is reflected in the ad note to Article VI:1 of the GATT, which allows investigation authorities to deviate from the normal methods to calculate dumping margins if the export country thas a complete or substantially complete monopoly of its trade and where all domestic prices are fixed by the State..$^{50}$ Currently, few WTO members satisfy such an extreme market condition, thus the main legal basis for using the surrogate price method is some members' ex ante commitments as provided in their accession protocols. In practice, the methods used to ascertain the surrogate price is decided by the anti-dumping legislation of the members. A typical one is to choose a market-economy country which is in the similar development stage with the export country as the 'surrogate country' and use the price for like products in that country as the normal value. ${ }^{51}$ If there are no like products in the surrogate country, the investigating party may consider the price of each input factor in producing the product in that country. ${ }^{52}$ The details of the methods vary from

47 ibid para $1(\mathrm{a})$.

48 ibid para $1(\mathrm{~b})$.

49 An example of NME is China, which stipulates in its WTO Accession Protocol that it accepts NME status. While the provision expired in December 2016.

5o See GATT (n 18) ad note 2 to Article VI Paragraph 1 ('... in the case of imports from a country which has a complete or substantially complete monopoly of its trade and where all domestic prices are fixed by the State, special difficulties may exist in determining price comparability for the purposes of paragraph 1 , and in such cases importing contracting parties may find it necessary to take into account the possibility that a strict comparison with domestic prices in such a country may not always be appropriate').

51 See Jane M Smith, 'US Trade Remedy Laws and Nonmarket Economies: A Legal Overview' (2013) Congressional Research Service Report, 2 <http://fas.org/sgp/crs/misc/RL33976 .pdf $>$ accessed 28 April 2019 . ibid 3 . 
case to case but the methodology is the same: using the price in a surrogate country in lieu of that in the export country to ascertain the normal value.

In the WTO, the surrogate price method is mainly used by the United States and the European Union (EU). For example, in $U S-A D / C V D$ (China), the United States initiated anti-dumping investigations on four products from China. For all of them, the United States used surrogate prices instead of domestic prices in China because it alleged that the industries concerned are not in market-economy condition. ${ }^{53}$ The next part will use the trade between these two countries as an example to explain how the devaluation of currency influences the determination of dumping margin under different methods.

\subsection{The Influence of Currency Devaluation on the Calculation of Dumping Margin}

Before quoting prices in US dollar, a Chinese export company normally sets a price in Chinese yuan, probably based on the total cost of the product including the cost of raw materials, producing, transportation, etc. plus the expected profit and then, it converts the price to US dollar with the current exchange rate. ${ }^{54}$ Therefore, if the government intervenes in the exchange rate market to devaluate yuan, which means that one US dollar is worth more Chinese yuan, the price of the export product in dollars will be lower than the price without the currency devaluation. The following paragraphs will discuss if, after an 'abnormal' devaluation of the Chinese yuan which is believed by some companies in the United States to be manipulated by the government and accordingly the US International Trade Commission (USITC) initiates anti-dumping investigations, how this devaluation will influence the determination of antidumping duties.

Under all the three normal methods, the fact that the value of a currency is below the 'fair' value does not alter the result of anti-dumping duty calculation. Under the 'domestic price' method and the 'constructive value' method where normal values are ascertained based on the domestic prices or costs in China, while the export price is in US dollar, there must be a process of currency conversion. To ensure a fair comparison, according to the Anti-Dumping

53 WTO, United States - Definitive Anti-Dumping and Countervailing Duties on Certain Products from China, Report of the Panel (22 October 2010) WT/DS 379/R, 2-7 (US - AD/ CVD). In the case, the United States used the NME method to calculate dumping margin and imposed anti-dumping duty concurrently with the countervailing duty on the same product, which caused the 'double remedies' problem.

54 It is possible that financial instruments such as Exchange Rate Agreements are used by the companies to avoid exchange rate fluctuation. While these circumstances are not discussed in this article since they will make the analysis unnecessarily complicated. 
Agreement, the normal values in yuan will be converted to dollar with the same exchange rate being applied on the date of sale. ${ }^{55}$ As such, whether the currency is devaluated will not be considered by the investigation authority the exchange rate used for conversion is the same as the one actually adopted by the exporter after currency devaluation rather than one speculated by the USTIC to reflect the 'fair' value. This means that, as a result of the currency devaluation, the conversion will make the normal value in dollar decrease to the same degree as that of the export price quoted by the exporters. Consequently, the part of the price drop caused by exchange rate misalignment will not be additionally counted in the dumping margin and thus not countervailed by the anti-dumping duty. The same logic applies to the circumstance where the 'third-country price' method is applied as both the normal value and the export price are identically affected by the currency devaluation.

By contrast, the surrogate price method can offset the drop in price caused by exchange rate misalignment. ${ }^{56}$ As explained above, this method uses the price of similar products in a third country as the normal value. It is important to note that the assumption of discussion here is that the value of the third country's currency is not manipulated. In the anti-dumping investigation, the USITC will select a market economy which is in the same development stage as China and use the price of like products or the price of the inputs in that country as normal values (the surrogate prices). In order to compare with the export price, the surrogate price will be in US dollar and is not influenced by the devaluation of yuan. ${ }^{57}$ At the same time, the export price in dollar goes lower as a result of the devaluation of yuan, which means that the gap between normal value and export price, i.e. the dumping margin, become larger. As such, the influence of exchange rate misalignment is calculated in the dumping margin. Therefore, when the USTIC decides to impose anti-dumping

55 According to art 2.4.1 of the Anti-Dumping Agreement, "[w] hen the comparison under paragraph 4 requires a conversion of currencies, such conversion should be made using the rate of exchange on the date of sale', and normally, 'the date of sale would be the date of contract, purchase order, order confirmation, or invoice, whichever establishes the material terms of sale'.

56 See Hudson, Bento de Faria and Peyerl (n 19) 73. The authors mention that 'since nonmarket methodologies involve the construction of the normal value on the basis of a third economy and hence a third currency, its use would preclude the insertion of the currency misalignment into the dumping margin by the methods discussed below'.

57 The surrogate price might be converted to US dollars by the investigation group in order to make comparison. However, as the discussion assumes that the third country does not manipulate its currency, the exchange rate used to covert currency can be deemed to be 'fair'. 
duties against the import products, it contributes to eliminating the price advantage caused both by dumping activities and by the devaluation of yuan. ${ }^{58}$

\section{Combating Currency Manipulation Through the Anti-Dumping Mechanism}

The analysis above indicates that the choice of methods of calculating the dumping margin determines whether the price advantage caused by currency devaluation can be eliminated by anti-dumping duties. This finding provides a new angle for the WTO to work against currency manipulation: although the WTO cannot directly regulate the issue through the current WTO agreements nor by concluding a new agreement with the IMF, it can indirectly eliminate the unfair trade advantage via the anti-dumping mechanism. The basic idea is that theWTO members amend the Anti-Dumping Agreement or add a footnote to GATT Article VI:1 to allow applying the surrogate price method in the antidumping investigations against imports from countries which are identified as currency manipulators. This identification should be formally conducted and published by the IMF in accordance with Article IV1(iii) of the IMF Articles of Agreement. Besides, the IMF bears the responsibility to announce in a timely manner when it finds that the exchange rate of such member has returned to the normal value. The other elements of anti-dumping investigations, for example, determination of injury, will remain the same as those in the current anti-dumping legal framework.

\subsection{Compatibility with WTO Rules and Cases}

Amendments of WTO treaties according to this new approach do have legal basis under the current WTO legal framework. It has been discussed above that the WTO and the IMF have a clear division of responsibilities on international trade and monetary issues. For the WTO, the primary concern is not the activity of currency manipulation per se but the trade distortion effect caused by the lower export price. The spirit of the anti-dumping mechanism is consistent with such an understanding - not to categorically prohibit dumping

$5^{8}$ In practice, the influence of currency devaluation may not be fully offset by the antidumping duty because a dumping margin merely determines the maximum amount of the duty - the importing country may apply a lower rate. As a result, the influence of dumping is not fully eliminated. However, this does not change the fact that the design of surrogate price method in the current WTO anti-dumping mechanism itself has already worked against currency devaluation. 
activities but allowing the impacted member to take actions against those causing or threatening material injury to its domestic industries.

The cooperation framework between the WTO and the IMF also builds the institutional cornerstone towards further regulation of currency manipulation. As discussed above, paragraphs 2 and 4 of GATT Article XV, as well as the Agreement between the IMF and the WTO, provide the legal basis for the WTO members and tribunals to adopt the IMF's finding with regards to a member's violation of Article IV1(iii) of the IMF Articles of Agreement. The WTO members and the DSB can directly use that finding as the basis for further decisions and actions. Besides, there has long been a tradition of cooperation between the two organizations in a range of issues. ${ }^{59}$ This thus opens the door for further cooperation on the regulation of the exchange rate issue.

Moreover, exchange rate issues are not totally excluded from the ambit of the WTO anti-dumping mechanism. Footnote 2 to paragraphs 2 and 3 of GATT Article VI stipulates that multiple currency practices ${ }^{60}$ can in certain circumstances 'constitute a form of dumping by means of a partial depreciation of a country's currency'.61 This footnote indicates that the anti-dumping mechanism in the WTO does take the influence of exchange rate into account, which leaves room for future negotiations on the coordination between exchange rate arrangements and the anti-dumping mechanism.

Another important issue is the compatibility of this proposal with the WTO case law. Previous DSB findings confirm that the anti-dumping mechanism only focuses on the price gap between normal values and export prices regardless of whether the price gap is caused by the export company's own low-pricing strategy or government actions or other social economic elements.

59 See generally Deborah E Siegel, 'Legal Aspects of the IMF/WTO Relationship: The Fund's Articles of Agreement and the WTO Agreements' (2002) 96 AJIL 561, 563-78.

6o Multiple currency practice refers to an '[a]ction by a member or its fiscal agencies that of itself gives rise to a spread of more than 2 percent between buying and selling rates for spot exchange transactions between the member's currency and any other member's currency would be considered a multiple currency practice and would require the prior approval of the Fund'. IMF, 'Selected Decisions and Selected Documents of the IMF, Thirty-Ninth Issue - Multiple Currency Practices - Policy' (1981) Decision No 679o-(81/43) <www .imf.org/external/SelectedDecisions/Description.aspx?decision=679o-(81/43)> accessed April 15, 2019. It may be conducted in forms of exchange taxes, exchange subsidies, multiple-price auctions, etc. See IMF, 'Annual Report on Exchange Arrangements and Exchange Restrictions 2017' (2018) AEIEA2017001, 21 <www.imf.org/en/Publications/Annual-Report -on-Exchange-Arrangements-and-Exchange-Restrictions/Issues/2018/08/10/Annual -Report-on-Exchange-Arrangements-and-Exchange-Restrictions-2017-44930> accessed 15 April 2019.

61 GATT (n 18) Interpretative Note Ad Article VI, paras 2 and 3(2). 
For example, in $U S-A D / C V D$, the United States levied anti-dumping duties and countervailing duties concurrently on the same product. This caused the 'double remedies' problem because, by using the NME method, the drop of price caused by the government's subsidy has already been calculated into the dumping margin and consequently, levying a countervailing duty will offset the effect of subsidy twice. ${ }^{62}$ The $A B$ in the case recognized that the 'double remedies' is problematic but not because of the method to calculate dumping margins; instead, it found that the imposition of the countervailing duty was not appropriate. ${ }^{63}$

Challenges to this article's proposal may arise from the AB's findings in $E U$ - Biodiesel as the case is believed to have 'remove[d] the flexibility of condemning State intervention and price distortions through anti-dumping measures'.64 In the case, the European Union imposed anti-dumping duties on biodiesel products from Argentina and adopted the constructed value method in its determination of dumping margin for the reason that 'the biodiesel market in Argentina was heavily regulated by the State. ${ }^{65}$ The controversial issue is that the investigation authority refused to use the records kept by the Argentinean producers to ascertain the costs of main raw materials (i.e. soybeans and soybean oil). Instead, it used an adjusted 'international price', claiming that the domestic price of soybeans was suppressed by Argentina's export tax system and thus failed to reflect the true value of raw materials. ${ }^{66}$ The adoption of surrogate price caused around $40 \%$ increase of dumping margin compared with that calculated according to the producers' real costs. ${ }^{67}$ In the dispute, the WTO AB interpreted Article 2.2 of the Anti-Dumping Agreement and Article VI:1(b)(ii) of the GATT and decided not to support EU's surrogate price method:

Article 2.2 does not specify precisely to what evidence an authority may resort. This suggests that, in such circumstances, the authority is not prohibited from relying on information other than that contained in the

\footnotetext{
62 US - AD/CVD (n 53) 199-202.

63 ibid 218.

64 Weihuan Zhou, 'Appellate Body Report on EU-Biodiesel: The Future of China's State Capitalism Under the WTO Anti-Dumping Agreement' (2018) 17 WTR 6og, 632.

65 WTO, European Union: Anti-Dumping Measures on Biodiesel from Argentina - Report of the Appellate Body (6 October 2016) WT/DS473/AB/R 19 (EU-Biodiesel).

66 ibid 19-21.

67 According to the EU, the dumping margin calculated based on the producers' records ranged from $6.8 \%-10.6 \%$, while that calculated based on the surrogate international price ranged from $49.1 \%-49.2 \%$.
} 
records kept by the exporter or producer, including in-country and outof-country evidence. This, however, does not mean that an investigating authority may simply substitute the costs from outside the country of origin for the 'cost of production in the country of origin'.68

According to this interpretation, Article 2.2 of the Anti-Dumping Agreement allows an investigation authority to take into account prices outside the country of origin as information to ascertain costs of production, while the investigating authority must still determine the normal value basing on the costs in the country of origin rather than a surrogate third-country price, as long as the records kept by the production companies in the former case reasonably reflect the actual costs. This finding has a significant influence on the conduct of anti-dumping investigations as it discourages the use of market distortion as an excuse to construct normal value with surrogate country prices. However, it would have gone too far to say that the findings indicate that the anti-dumping mechanism should merely focus on company-level business practices rather than State-level policies. ${ }^{69}$ Circumstances where WTO members have committed additional obligations regarding their market status, for example, China's Accession Protocol regarding its NME status, are recognized and treated by the $A B$ as special cases where the surrogate country method can be directly applied without consideration of the exporting country's domestic prices. ${ }^{70}$ This means that the anti-dumping mechanism does take into account the impact of State intervention on the determination of dumping margins, however only under circumstances where states make ex ante commitments in addition to the general obligations. This understanding does not conflict with using the surrogate method against currency manipulation as proposed by this article. On the contrary, it suggests that imposing an additional obligation addressing currency manipulation to the anti-dumping laws, like that of the NME status,

$68 \quad E U-$ Biodiesel (n 65) 43 .

69 Cf Zhou (n 64) 638.

$70 \quad$ EU - Biodiesel (n 65) para 6.87; WTO, European Communities: Definitive Anti-Dumping Measures on Certain Iron or Steel Fasteners from China (Article 21.5 Appellate Body Report), Report of the Appellate Body (18 January 2016) WT/DS397/AB/RW, para 5.207 ('Article 2.4 of the Anti-Dumping Agreement has to be read in the context of the second Ad Note to Article VI:1 of the GATT 1994 and Section 15(a) of China's Accession Protocol. We recall that the rationale for determining normal value on the basis of the domestic prices of Pooja Forge was that the Chinese producers had not clearly shown that market economy conditions prevail in the fasteners industry in China ... the investigating authority is not required to adjust for differences in costs between the NME producers under investigation and the analogue country producer where this would lead the investigating authority to adjust back to the costs in the Chinese industry that were found to be distorted'). 
can be a legitimate avenue allowing investigation authorities to use surrogate prices in anti-dumping investigations against currency manipulators.

Indeed, a similar idea of combating currency manipulation through the antidumping mechanism, but with a different approach to calculating dumping margin, was proposed in a Congress bill in the United States. ${ }^{71}$ It was criticized by some scholars that '[d]umping is a matter of companies' product pricing decisions, which have nothing to do with the macro-level governmental measures that lead to exchange rate misalignment. ${ }^{72}$ However, this argument lacks support from legal texts and practices. No text in GATT or the Anti-Dumping Agreement suggests that private companies are the only actors involved in dumping practice. The nature of anti-dumping is 'anti-price-discrimination' and elements beyond the export company's activities can also contribute to such discrimination. ${ }^{73}$ Besides, as explained above, the existence of the NME method in the current anti-dumping mechanism as well as the cases relating to 'double remedies' reveal that the WTO does not prohibit the members from counting the influence by State activities on price distortion in the calculation of dumping margin, which also means that dumping is not merely related to company-level factors.

\subsection{Feasibility of the Proposed Method}

Compared with previous proposals, this proposal is technically and practically more feasible. Technically, there is no need for the WTO to develop new

71 Govtrack, 'S. 3134 (111th): Currency Exchange Rate Oversight Reform Act of 2010' (17 March 2010) sec $105<$ www.govtrack.us/congress/bills/111/s3134/text/is> accessed 28 April 2019. Section 105 of the bill specifically requires the investigation authority to '[adjust] the price used to establish export price or constructed export price to reflect the fundamental misalignment of the currency [emphasis added] of the exporting country'. For example, assuming that a Japanese company sells a product for 200 yen domestically and exports it for 1 US dollar. The current exchange rate is 1 dollar: 150 yen, while the investigation authority believes that the equilibrium exchange rate should be 1 dollar: 100 yen. In this circumstance, according to the proposal, the investigation authority should convert the export price (1 dollar) with the equilibrium exchange rate (1:100) instead of the exchange rate influenced by currency manipulation (1:150) and compares it with the normal value (200 yen). With this method, the dumping margin will be higher than normal method. However, the proposal does not explain how to determine the degree of the 'misalignment of the currency of the exporting country', which makes it technically difficult to be implemented.

72 Zimmermann (n 19) 457. Staiger and Sykes hold the same opinion that dumping is a firmlevel activity rather than government-level. See Staiger and Sykes (n 19) 615 .

73 See WTO, 'Technical Information on Anti-dumping' <www.wto.org/english/tratop_e/ adp_e/adp_info_e.htm> accessed 28 April 2019. Dumping can be deemed as a discrimination between domestic consumers and the import country's consumers. 
technical standards on the identification of currency manipulation. Under this approach, to determine whether the surrogate price should be applied in antidumping investigations, the WTO members simply rely on the IMF's findings on whether a member violates Article IV of the IMF Articles of Agreement. Nor is it necessary to undertake the impossible task to design a fair and accurate method to calculate the degree of currency misalignment, as the members can directly use domestic price in a third country as the surrogate price for the entire anti-dumping investigation. ${ }^{74}$ The only change to the current Anti-Dumping Agreement is to add a provision allowing the members to apply the surrogate price method in anti-dumping investigations against currency manipulators.

Besides, substantively no additional obligations are imposed to the current legal systems because the only condition to trigger the application of the surrogate price method is that the member violates one existing obligation Article IV of the IMF Articles of Agreement. Thus, this new proposal works, more or less, as an enforcement mechanism of Article IV of the IMF Articles of Agreement. For the WTO members, there is no risk to be complained to the DSB for an alleged activity of currency manipulation because currency manipulation per se still does not violate any WTO rules. As such, a member cannot challenge it to the WTO and require another member to quit the intervention activities or to take measures to bring the exchange rate to a normal level. On the IMF side, the new method will not impose extra pressure with regards to currency policy reviews as well since the procedure and standards for the reviews will remain the same as those prescribed in the IMF Articles of Agreement. This makes the new method more likely to be accepted by states compared with other means of regulation.

If the problem of currency manipulation is to be solved by the WTO, compared with directly identifying currency manipulation as a violation of WTO obligations, this new approach has more advantages in terms of maintaining the coherence of the WTO legal system. Previous proposals, including those identifying currency manipulation as a subsidy or suggesting a new cooperation agreement between the IMF and the WTO, unreasonably expand the regulatory scope of the WTO. The WTO and the IMF have a clear specialization of duties between trade issues and monetary issues. This can be confirmed by GATT Article XV:1 which requires the WTO to consult the IMF on certain

74 See Avgouleas (n 6) ('determining the existence and extent of currency misalignment, especially as a possible trigger for remedial action, has historically proven enormously difficult both intellectually and politically'). 
currency issues instead of making decisions independently. ${ }^{75}$ Therefore, escalating currency issues into legally binding WTO obligations would push the institution beyond its limits. ${ }^{76}$ With the surrogate price approach, since the IMF retains the jurisdiction over the identification of currency manipulation, the division of duties is essentially respected.

Last but not least, compared with directly regulating currency manipulation, the approach works better in terms of balancing the goal of promoting free trade and the goal of eliminating trade distortion. Unlike subsidy and dumping, currency manipulation does not occur to specific enterprises or industries but influences every cross-border transaction. That is to say, if the government of the importing country decides to levy a single anti-currency-manipulation duty, it increases the level of tariff on all products from the export country, which excessively rectifies the trade distortion effect. Binding tariffs, which means that the members are obligated to keep the tariff level as committed and avoid increasing the tariff, is a core principle of the WTO, and anti-dumping and countervailing duties are merely exceptions to this principle. ${ }^{77}$ The impact of an anti-currency-manipulation duty as a trade barrier is much severer than anti-dumping and countervailing duties because it worsens the entire trade condition between the exporting country and importing country, which deviates too far from the principle of binding tariff and the goal of promoting free trade. By contrast, by counting the influence of currency manipulation in the anti-dumping investigation, the target of import duty is limited to specific enterprises or industries which cause material injuries to the import country's industries. In other words, it ensures that the punitive tariff is levied to an appropriate degree. ${ }^{78}$

\subsection{Potential Challenges to the Proposed Approach}

Despite the above advantages, it would not be surprising that the new approach would be subject to various challenges. The first and most straightforward

75 GATT (n 18) art XV:1.

76 See Jim Bacchus, 'Don't Push the WTO Beyond Its Limits' (The Wall Street Journal, 25 March 2010) para $12<$ www.wsj.com/articles/SB10001424052748703312504575141653709 335366> accessed 28 April 2019.

77 See WTO, 'Anti-dumping, Subsidies, Safeguards: Contingencies, etc' <www.wto.org/ english/thewto_e/whatis_e/tif_e/agrm8_e.htm> accessed 28 April 2019.

78 For example, if after the currency devaluation, an exporting company decides not to adjust the export price with the new exchange rate and keeps the previous export price, the company, in fact, does not gain price advantages from the devaluation. In this scenario, it should not be imposed with punitive duty. In this case, if the import country levies an overall tariff against currency manipulation, this 'innocent' company would have to pay extra tariff, which is obviously unreasonable. 
challenge is that there might be disagreement from some WTO members to adopting the surrogate-price method in anti-dumping investigations, which makes the implementation of the approach unfeasible. For example, China has formally requested the United States to stop using the 'surrogate country' in calculating anti-dumping margins ${ }^{79}$ and has filed two cases regarding the issue to the WTO. ${ }^{80}$ According to China, the EU and the US's so-called 'NME' methods against Chinese imports 'ceased to be justifiable when paragraph 15(a)(ii) of China's Accession Protocol expired on 11 December 2016 and is inconsistent with the WTO covered agreements'. ${ }^{81}$ This thus caused intense debates over whether China can be automatically granted the market economy status after 2016. ${ }^{82}$ China does take a clear and firm position against the discriminative NME treatments provided by some WTO members' antidumping laws. However, it would have gone too far to say that China is against the surrogate price method per se; rather, it is challenging the legality to adopt the method on the premise that the main legal basis underpinning the differential treatment to 'NMEs', i.e. paragraph 15(a)(ii) of China's Accession

79 WTO, 'Annual Report 2018' 67 <www.wto.org/english/res_e/booksp_e/anrep18_e.pdf>accessed 26 April 2019.

8o See WTO, 'China Files WTO Complaint Against US, EU Over Price Comparison Methodologies' (2016) <www.wto.org/english/news_e/news16_e/ds515_516rfc_12dec16_e .htm> accessed 28 April 2019.

81 WTO, 'European Union: Measures Related to Price Comparison Methodologies - Request for the Establishment of a Panel by China' (10 March 2017) WT/DS516/9, para 11. Provision 15(a)(ii) of China's Accession Protocol stipulates that an importing member is allowed to use the NME method if the company under investigation is not in an industry where market economy conditions prevail, while Provision ${ }_{15}$ (d) states that ' [i]n any event, the provisions of subparagraph (a)(ii) shall expire 15 years after the date of accession'. However, on 7 May 2019, China requested the Panel to suspend its proceedings and the request was granted by the Panel on 14 June 2019. See WTO, European Union: Measures Related to Price Comparison Methodologies, Communication from the Panel (17 June 2019) WT/DS516/13.

82 See Laura Puccio, 'Granting Market Economy Status to China' (European Parliamentary Research Service, November 2015) 1 <www.europarl.europa.eu/RegData/etudes/IDAN/ 2015/571325/EPRS_IDA(2015)571325_EN.pdf> accessed 28 April 2019; Sherzod Shadikhodjaev, 'Non-Market Economies, Significant Market Distortions, and the 2017 EU Anti-Dumping Amendment' (2018) 21 JIEL 885; Weihuan Zhou and Delei Peng, 'EU - Price Comparison Methodologies (DS516): Challenging the Non-Market Economy Methodology in Light of the Negotiating History of Article 15 of China's WTO Accession Protocol' (2018) 52 JWT 505; Ritwik Bhattacharya, 'Three Viewpoints on China's NonMarket Economy Status' (2019) 9 Trade, Law and Development 305; James J Nedumpara and Weihuan Zhou (eds), Non-Market Economies in the Global Trading System: The Special Case of China (Springer 2018). 
Protocol, have ceased to exist. ${ }^{83}$ It might still be argued that since countries like China has long been accused of manipulating their currencies, they are unlikely to support further regulation under the WTO framework. However, as mentioned at the beginning, the aim of the article is to point out a relatively feasible alternative - any reform will inevitably encounter resistance and the value of this article is that in future when there is a general consensus among WTO members to address the issue, the new approach proposed here could provide a more feasible solution.

Another possible challenge is that the proposed approach may cause the abuse of the surrogate price method. This is a reasonable concern given that some WTO members have been using various excuses to apply the method inappropriately. In the end, they were found by the WTO panels or the AB to either lack legal basis (e.g. the $E U$ - Biodiesel case) or have excessively adjusted trade distortions (the 'double remedy' problem), not to the mention the ongoing debate over some members' biased NME treatment in their anti-dumping legislation and practice. Besides, adopting the surrogate price method in antidumping investigations encompasses the risk of selecting surrogates that are not at the same level of economic development as that of the country being investigated, for example, using the UK as a surrogate for China. ${ }^{84}$ These problems, however, do not exist in the method proposed here. Under the current anti-dumping law framework, the main cause of the abuse is that the decision as to whether and how to apply the surrogate price method is largely at the discretion of each member state's investigation authorities. They may claim that their interpretation and implementation of relevant WTO rules are correct until they get sued and lose the case in the WTO. By contrast, as explained above, the sole basis under the proposed approach for applying the surrogate price method for the reason of currency devaluation is that the IMF has officially found a member violate Article IV1(iii) of the IMF Articles of Agreement. This will prevent the investigation authorities to arbitrarily use the method out of their own expansionary explanation of rules. With regards to the problem of

83 MOFCOM, 'Opening Statement by Ambassador Zhang Xiangchen as a Part of the Oral Statement of China at the First Substantive Meeting of the Panel in the Dispute: European Union - Measures Related to Price Comparison Methodologies (DS516)' (10 December 2017) para 7 <http://wto2.mofcom.gov.cn/article/chinaviewpoins/201712/20171202684583 .shtml> accessed 26 April 2019 ('when Section 15[a][ii] of China's Accession Protocol expired ... there is no longer any basis under the Protocol to abandon home market prices and costs'). See also Xuewei Feng, 'The Termination of the Grandfather Clause in China's Accession Protocol and the Normal Value Construction After Fifteen Years of Accession' in Nedumpara and Zhou (n 82) 99.

84 Joseph E Stiglitz, 'Dumping on Free Trade: The US Import Trade Laws' (1997) 64 Southern Economic Journal 402, 413 . 
the selection of surrogates, it can be solved by providing more detailed guidance in the amended rules.

The IMF's prudent attitude towards finding a violation of Article IV1(iii) can also reduce the risk of abusing the surrogate method. Up to now, although the Executive Board of the IMF conducts consultations on Article IV1(iii) with a number of members every year, it has never formally found a violation of the article. Indeed, in 2008, the IMF prepared an Article IV1(iii) report on China which contained an accusation of a fundamental misalignment of the renminbi; however, it was never published because the financial crisis burst and the United States needed China's cooperation to mitigate the impact. ${ }^{85}$ This shows that, with the increasing influence of emerging market economies on international politics, the IMF can be expected to reach more balanced decisions regarding its members' exchange rate policies.

To conclude, the approach proposed in this article, which is to use prices in surrogate countries as the normal values in anti-dumping investigations against currency manipulators, bridges the WTO and the IMF with regards to the regulation of currency manipulation while avoiding blurring the boundaries between the two institutions in terms of their functions and responsibilities. As emphasized in the beginning, this article does not intend to design a perfect new mechanism to combat currency manipulation but simply to point out a possible new avenue. More detailed standards and procedures, for example, the selection of surrogate countries and the determination of the manipulation period, can be discussed in future studies.

85 Blustein (n 30) 9 . 